\title{
COVERAGE MOBILIZATION IN THE SOWING LINE AND ITS INFLUENCE ON TEMPERATURE AND WATER CONTENT AND ON MAIZE EMERGENCE
}

Doi:http://dx.doi.org/10.1590/1809-4430-Eng.Agric.v35n 1p98-108/2015

\section{EVANDRO M. BRANDELERO ${ }^{1}$, AUGUSTO G. DE ARAÚJO ${ }^{2}$, RICARDO RALISCH ${ }^{3}$}

\begin{abstract}
Straw on sowing line modifies seed germination environment regarding temperature and water content. Given these considerations, the aim of this study was to evaluate different mechanisms for coverage mobilization on the sowing line and their effect on germination environment of maize seeds, mainly in relation to the dynamics of straw in the seedbed, water content and soil temperature. Treatments consisted on the combination of two mechanisms at front of furrow opener, composed of cutting disc and row cleaners, with three mechanisms behind the seed furrower for returning the soil, consisting of three covering mechanisms, commercial and prototype models. It was found that straw presence on the surface of sowing line contributed to germination of maize seeds, maintenance of temperature and soil water content. The cutting disc treatment, associated with prototype, introduced percentages of water content near the ones in bottom layer, and this soil water content was $29.7 \%$ with $93.75 \%$ of straw coverage and deeper seeding depth, granting better conditions for seed germination. However, the straw coverage removal on soil by the row cleaners and its low sowing depth caused water loss in the lines resulting in great reduction of the emergence speed index in maize seedlings.
\end{abstract}

KEYWORDS: no-tillage planting, germination environment, furrowers, soil coverage.

\section{MOBILIZAÇÃO DA COBERTURA VEGETAL NA LINHA DE SEMEADURA E SUA INFLUÊN CIA NA TEMPERATURA E CONTEÚDO DE ÁGUA NO SOLO E NA EMERGÊNCIA DO MILHO}

\begin{abstract}
RESUMO: A presença da palha sobre a linha de semeadura modifica o ambiente germinativo das sementes quanto à temperatura e ao conteúdo de água. Diante destas considerações, o objetivo do trabalho foi avaliar diferentes mecanismos para a mobilização da cobertura vegetal na linha de semeadura e sua influência na qualidade do ambiente germinativo de sementes de milho, principalmente em relação à presença de palha na linha, ao conteúdo de água e à temperatura do solo. Os tratamentos consistiram na combinação de dois mecanismos à frente da haste sulcadora, compostos do disco de corte e das rodas de varredura, com três mecanismos atrás do sulcador da semente, envolvendo modelo comercial e protótipos produzidos. Constatou-se que a presença da palha sobre a superfície da linha de semeadura contribuiu para a germinação das sementes de milho, a manutenção da temperatura e da água no solo. Já o tratamento disco de corte, associado ao protótipo, apresentou percentuais de conteúdo de água próximos aos da camada inferior, sendo este conteúdo de água no solo de $29,7 \%$, com $93,75 \%$ de cobertura com palha e a maior profundidade de semeadura, conferindo melhores condições para a germinação das sementes. Entretanto, a remoção da cobertura da palha sob o solo pelas rodas de varredura e sua baixa profundidade de semeadura causaram a perda de água do solo na linha de semeadura, resultando em grande redução no índice de velocidade de emergência nas plântulas de milho.
\end{abstract}

PALAVRAS-CHAVE: semeadura direta, ambiente germinativo, sulcadores, cobertura do solo.

\footnotetext{
${ }^{1}$ Eng $^{\circ}$ A grônomo, Prof. Doutor, Coordenação de A gronomia, UTFPR-DV / Dois Vizinhos - PR, Fone: (46) 3536-

8900, ebrandelero@utfpr.edu.br.

${ }^{2}$ Eng $^{\circ}$ A grícola, Pesquisador Doutor, Área de Engenharia Agrícola, IAPAR / Londrina - PR, agaraujo@iapar.br.

${ }^{3}$ Eng $^{\mathrm{o}}$ A grônomo, Prof. Doutor, Departamento de Agronomia, UEL / Londrina - PR, ralisch@uel.br.

Recebido pelo Conselho Editorial em: 10-7-2012

Aprovado pelo Conselho Editorial em: 27-7-2014
} 


\section{INTRODUCTION}

Straw on soil surface is a technical recommendation to reduce erosive processes by rainwater and wind, assisting in the sustainability of agricultural cultivation (VEIGA et al., 2010). Nevertheless, straw mobilization in No-tillage system (NTS) requires seeders with adapted furrowers for the cutting (CEPIK et al., 2010) or side dislocation, as well as for its return on sowing line (BRANDELERO et al., 2012a) which can contribute for the finishing quality of sowing. The study of the relationship soil-machine-plant contributes to a great initial establishment of plants (ROSA, 2009), as the intensification of machine traffic acts on the increase of soil compaction and reduction of root growth (ROSA et al, 2008).

No-tillage seeders present different performances regarding soil preparation (CHIODEROLI et al., 2010), traffic intensity (ROSA et al., 2012) and soil mobilization (CONTE et al., 2009). The modification of seeders-fertilizers with furrower mechanisms for NTS contributes to diminish the number of interruptions derived from straw accumulation, along with acting on the reduction of exposed soil, improving maize final population (ARATANI et al., 2006).

In annual crops, no-tillage is carried out with seeders-fertilizers that prepare the soil on sowing line, using furrower mechanisms for straw mobilization and deposition of fertilizers and seeds on soil (ARATANI et al., 2006), as well as landing mechanisms to improve coverage and contact soil-seed (BRANDELERO et al., 2012b). These furrowers provide an effect on sowing line, modifying soil physical environment concerning mobilized area and sowing dept (FALLAHI \& RAOUFAT, 2008). The most used furrowers in no-tillage seeders are shanks and double discs (LEVIEN et al., 2011). For an adequate sowing, the machine should also transpose the soil coverage. To achieve that, it is most frequently employed the plane cutting discs at the front of a shank type furrower (SANTOS et al., 2008).

An alternative for the cutting discs is the row cleaner system that consis ts of two engaged and sprocket convergent wheels working to move the straw away laterally, instead of cutting it like the discs (FALLAHI \& RAOUFAT, 2008).

The relocation of straw to the side of sowing line favors seed germination environment as it introduces straw in the line interior, improving contact soil-seed and granting a good plant population (BRANDELERO et al., 2012a). The perpendicular angulations of the row cleaners as well as the parallel direction of straw accommodation acts positively reducing straw introduction in the interior of the sowing line (KORNECKI et al., 2009).

The presence of straw on sowing line contributes for the maintenance of soil water content and reduces temperature (BRANDELERO et al., 2012b). Therefore, in the interest of the straw contributing to soil water maintenance, this should be evenly distributed on soil in adequate quantities, favoring seed germination (FALLAHI \& RAOUFAT, 2008). Straw on soil proportionates mild and adequate temperatures for great seed germination in tropical climate conditions, when compared to uncovered soil (BRANDELERO et al., 2012b).

In the sowing process, the straw can also be removed only in the sowing line, enabling a localized rise in temperature through greater exposition of sunlight, a technique used in soils of mild climates to improve germination percentage (FALLAHI \& RAOUFAT, 2008).

This study aimed to evaluate different mechanisms of straw mobilization, combining the use of cutting disc and row cleaners with different return mechanisms of soil and straw on the sowing line, and its influence on soil moisture and temperature and maize emergence.

\section{MATERIAL AND METHODS}

The work was conducted in the experimental area of the Agronomic Institute of Paraná (IAPAR) in Londrina - PR - Brazil, at $23^{\circ} 37^{\prime} \mathrm{S}$ and $51^{\circ} 17^{\prime} \mathrm{W}$. The soil was classified as Dystroferric Red Latosol (Oxisol) and was under no-tillage system for 21 years. The 
Climatological Station of IAPAR conceded the climatological data during the experiment conduction (Figure 1).

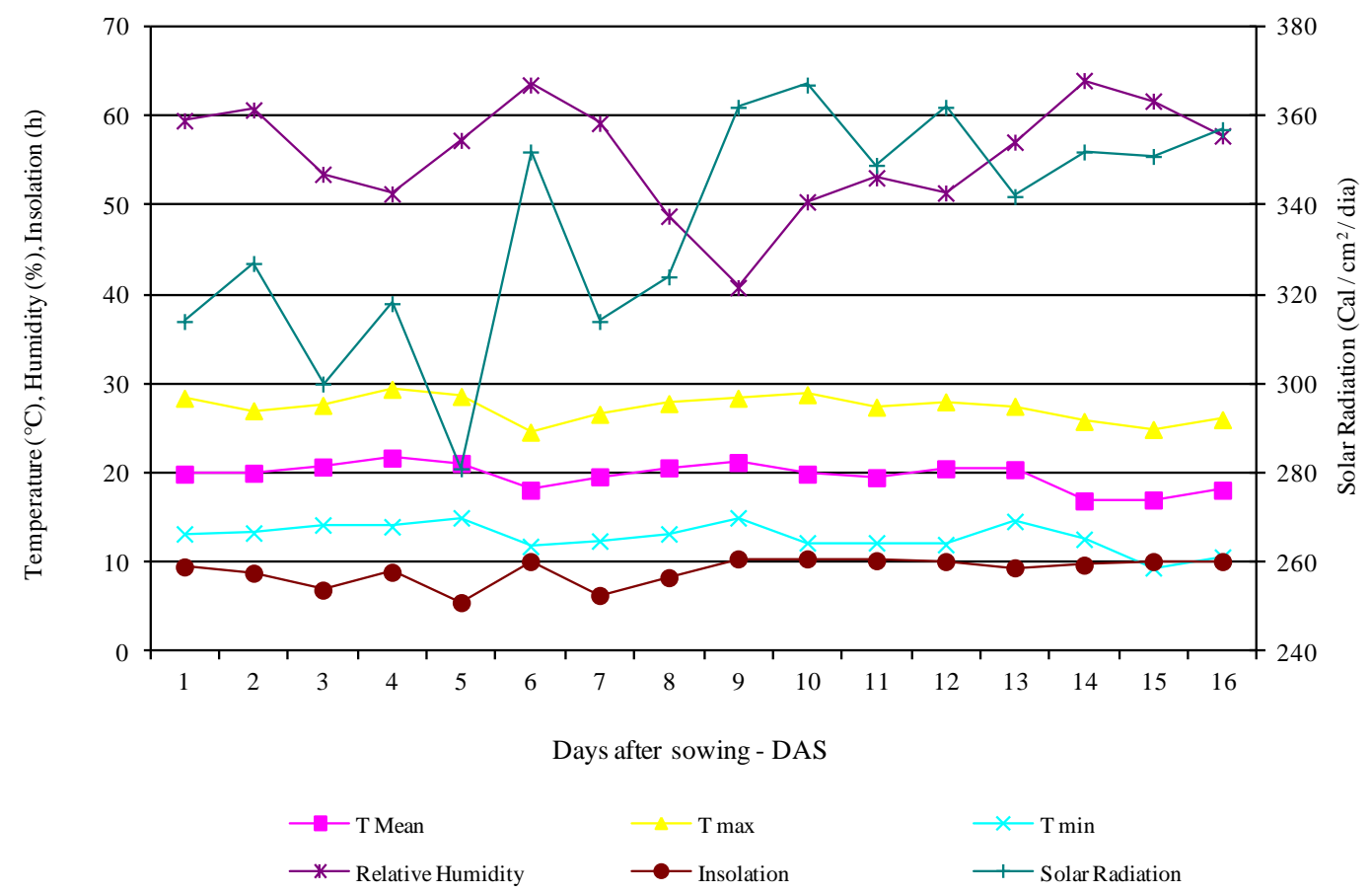

FIGURE 1. Meteorological data from the climatological station IAPAR during the experimental period related to maximum, minimum and average air temperature, air relative humidity, solar insolation and radiation.

The experiment was covered with sorghum residue handled using plant residue shredder, presenting an average of $10.7 \mathrm{Mg} \mathrm{ha}^{-1}$ of dry mass. For the sowing operation, a tractor of $85 \mathrm{CV}$, weighting $4,420 \mathrm{~kg}$ was used in an average speed of $1.6 \mathrm{~m} \mathrm{~s}^{-1}$.

For treatment realization, a no-tillage seeder Jumil brand was used with a sowing line, containing: shank type fertilizer furrower, out of phase double disc type seed furrower, controller wheel of seed depth and plane compactor wheel. The experiment was established in a randomized block design with four repetitions and seven treatments, with these constituting of mechanisms for straw mobilization on sowing line.

A 30-m-long sowing line composed experimental plots such as described on Table 1 and Figure 2, these plots were $3 \mathrm{~m}$ apart from each other.

The treatments consisted of the combination of two mechanisms at front of furrow opener, composed of cutting disc and row cleaners, and three mechanisms behind the seed furrower for soil return, composed of covering discs commercial model, prototype M1 and Spider, with the combination of cutting disc and Spider model not being evaluated due to experimental area limitation. 
TABLE 1. Treatments consisting of the combination of the straw mobilization mechanisms placed in front of the shank type furrower (anterior) and behind the depth controller wheels (posterior).

\begin{tabular}{lll}
\hline Treatments & Anteriors & Posteriors \\
\hline $\mathrm{CD}+\mathrm{CM}$ & Cutting disc & Covering discs comercial model \\
\hline $\mathrm{CD}+\mathrm{M} 1$ & Cutting disc & Covering disc prototype M1 model \\
\hline $\mathrm{CD}$ & Cutting disc & No mechanism \\
\hline $\mathrm{RC}+\mathrm{CM}$ & Row cleaners & Covering disc comercial model \\
\hline $\mathrm{RC}+\mathrm{M} 1$ & Row cleaners & Covering disc prototype M1 model \\
\hline $\mathrm{RC}+\mathrm{SM}$ & Row cleaners & Covering disc Spider model \\
\hline $\mathrm{RC}$ & Row cleaners & No mechanism \\
\hline
\end{tabular}

The utilized maize cultivar was AG1051 in the proportion of 8.0 seeds $\mathrm{m}^{-1}$ from previous seeder regulation. The physiological analysis introduced that the seeds exhibited $96 \%$ of germination and $99 \%$ of normal seedlings. The mechanism, termed row cleaners (RC), consisted of two plane metallic discs presenting sharp edges in bezel, working engaged and moving through the contact of edges with soil, and when operating they move straw laterally to the sowing line, without cutting it. The cutting disc mechanism (CD) consisted of a plane metallic disc, located at front of the other seeder active devices, and performed straw cutting function, using soil as protection.
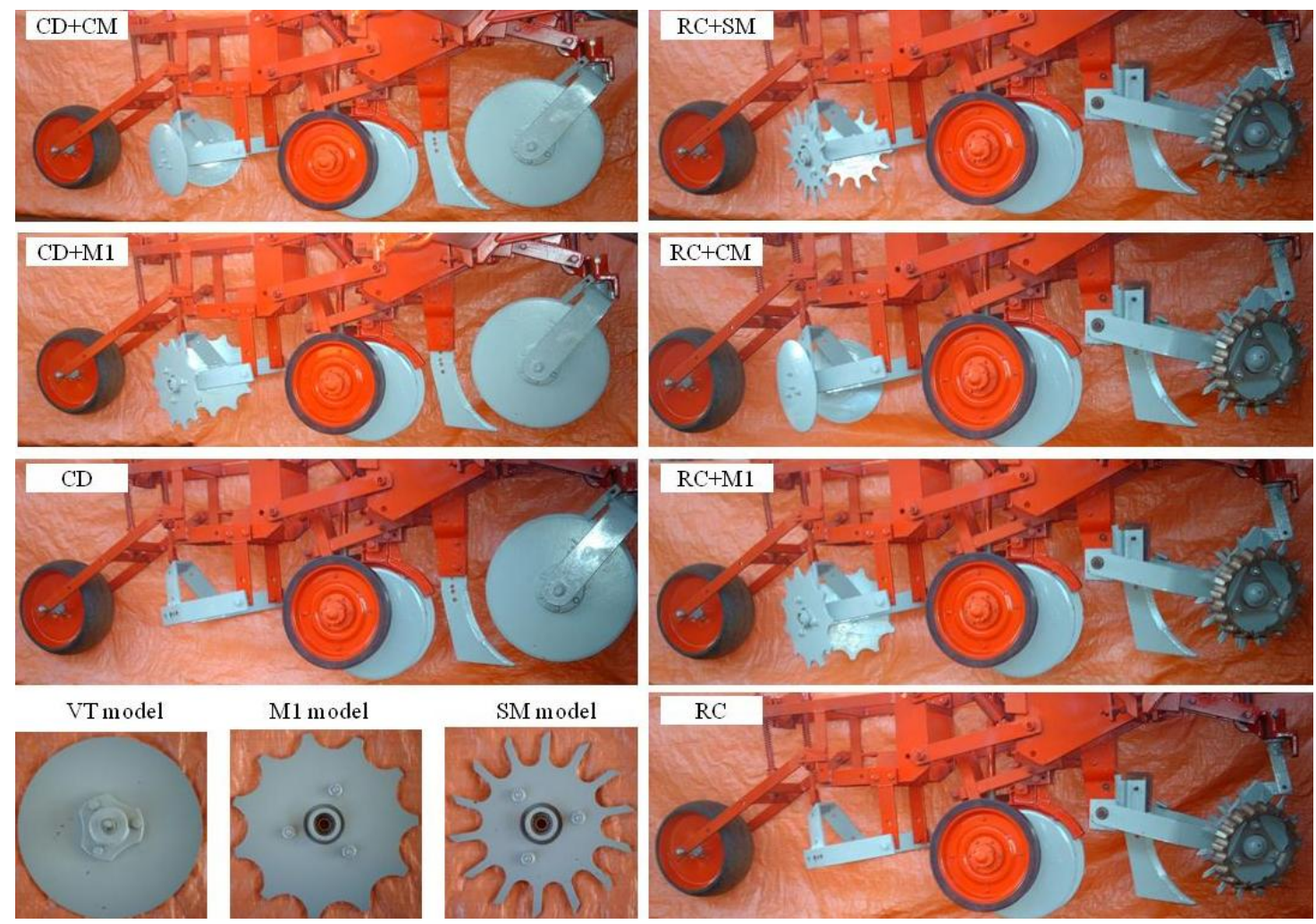

FIGURE 2. Configurations of straw mobilization mechanisms applied to treatments: CD+CM, cutting disc plus cover commercial model; CD+M1 cutting disc plus cover model 1; $\mathrm{CD}$, cutting disc with no posterior mechanism; $\mathrm{RC}+\mathrm{CM}$, row cleaner plus cover commercial model; RC+M1, row cleaner plus cover model 1; RC+SM, row cleaner plus cover spider model; RC, row cleaner without posterior mechanism; Model MC, cover commercial model; Model M1, cover model 1, and Model MS, cover spider model.

The posterior sets are also known as covering discs aimed to move the soil and straw from the side to center of line after sowing. They are placed laterally and after the seed furrower, in oblique 
position in relation to seeder movement, one in each side of sowing line. The models varied according to tool format. The MC model, based on the model commercially used by rural producers, consisted of two concave metallic discs, with plane edge. The covers M1 prototype model are two plane metallic discs with semicircular indentations, forming a jagged edge, distant from each other and placed in an oblique position in relation to sowing line. The covers MS, Spider model were two plane metallic that present edges in bezel.

In order to describe the treatments effects, straw coverage on soil, temperature and soil moisture on sowing line, water content, seed depth and seedling emergence of maize were evaluated.

The vegetal coverage percentage (straw) on the line surface was quantified using a measuring tape of $15 \mathrm{~m}$ length, with equidistant markings of $0.15 \mathrm{~m}$ placed centrally in the sowing line and its result was obtained directly through the counting of number of points interceded with straw under the tape (LAFLEN et al., 1981).

The soil temperature was registered daily, from the first to fifteenth day after sowing, at 09:00am and 03:00pm, using a direct reading geotermometer of mercury (BRANDELERO et al., $2012 \mathrm{~b}$ ), which was installed on sowing line of each treatment at $0.05 \mathrm{~m}$ of depth.

In order to evaluate the soil water content in the interior of sowing line, deformed soil samples were collected in four occasions and in each plot, one at depth of 0 to $0.06 \mathrm{~m}$ in the day of sowing, and the others at two depths ( 0 to $0.3 \mathrm{~m}$ and 0.031 to $0.06 \mathrm{~m}), 24$ hours after sowing, in the beginning and end of seed emergence. Aluminum rings of $184.6 \mathrm{~cm}^{3}$ were used to collect the soil. Afterwards, the capsules were sealed with plastic tape to avoid water loss and then the samples were weighted and stored in kiln at $105^{\circ} \mathrm{C}$ until constant weight were reached. After drying, the samples were weighted for density and soil water content calculation (EMBRAPA, 1997).

Before sowing, germination analysis of maize seeds regarding percentage of normal seed lings and fast ageing in the seed laboratory of IAPAR were carried out. In field, emergence percentage was determined by counting the number of seedlings emerged at each day, at $10.0 \mathrm{~m}$ of each plot, starting from the day that the first seedling emerged, until the non-occurrence of emergence, defined as emergence stability (BRANDELERO et al., 2012b). The emergence speed index was obtained dividing the percentage of emerged seedlings in each day, by the number of days from sowing to emergence (KOAKOSKI et al., 2007).

The quantification of seed water content (S.W.C.) was conducted 24 hours after sowing. Twenty seeds per plot were manually collected and stored in a hermetically closed container to avoid dehydration. Subsequently, the humid seeds were weighted and taken to air forced circulation chamber until constant weight, assessing the dry weight. After seed drying, seed water content was calculated (CARVALHO, 2000).

Seed depth was estimated by collecting ten seedlings per plot after emergence, to meas ure the distance between the base of seed hypocotyl (in soil interior) and the beginning of stem superior part (outside the soil), where chlorophyll presence started (BRANDELERO et al., 2012b).

After data collection, the values were submitted to Levene test for homoscedasticty verification. Afterwards, analysis of variance was conducted and when significant differences at 5\% of error probability occurred, the averages were compared to each other by the Tukey test at $5 \%$ using the statistical program Statistica 6.1 version. In addition, the relation between data sets of analyzed variables was evaluated, an analysis of simple linear correlation was carried out (r) and then its significance by $\mathrm{T}$ test at 1 and $5 \%$ probability was compared using the computing program ASSISTAT 7.6 version proposed by SILVA \& AZEVEDO (2009). 


\section{RESULTS AND DISCUSSION}

The results of seed water contents (S.W.C), 24 hours after sowing showed that treatment $\mathrm{CD}+\mathrm{CM}$ displayed the highest percentage, with $41.5 \%$ of humidity (Table 2 ), significantly differing from treatments $\mathrm{RC}+\mathrm{M} 1$ and $\mathrm{RC}$, with 35.9 and $36.1 \%$, respectively. Treatment $\mathrm{RC}$ introduced the lowest soil water content (24\%) (Table 2), significantly differing from CD+CM with $32 \%$. The greatest contact of seeds with soil water content in treatment $C D+C M$ favored the highest seedwater content. According to CARVALHO (2000), the increase in seed water content intensifies their respiratory activity, which will degrade reserve substances and, in its turn, will nourish the growth of embryonic axis, enabling in the following stage, better performance of germination process.

TABLE 2. Water content in soil and seeds (\%) 24 hours after sowing, seedling emergence of maize $(\%), 8-15$ days after planting and emergence speed index - ESI $\left(\% \operatorname{dia}^{-1}\right)$.

\begin{tabular}{lccc}
\hline \multirow{2}{*}{ Treatments } & $\begin{array}{c}\text { Soil water content } \\
\%\end{array}$ & $\begin{array}{c}\text { Seed-water content } \\
\%\end{array}$ & $\begin{array}{c}\text { ESI } \\
\text { day }\end{array}$ \\
\hline $\mathrm{DC}+\mathrm{MC}$ & $32 \mathrm{a}$ & $41.5 \mathrm{a}^{*}$ & $31.0 \mathrm{a}$ \\
\hline $\mathrm{DC}+\mathrm{M} 1$ & $29 \mathrm{ab}$ & $37.7 \mathrm{ab}$ & $34.9 \mathrm{a}$ \\
\hline $\mathrm{DC}$ & $27 \mathrm{ab}$ & $38.8 \mathrm{ab}$ & $33.0 \mathrm{a}$ \\
\hline $\mathrm{RC}+\mathrm{MC}$ & $27 \mathrm{ab}$ & $40.2 \mathrm{ab}$ & $28.7 \mathrm{a}$ \\
\hline $\mathrm{RC}+\mathrm{M} 1$ & $31 \mathrm{a}$ & $35.9 \mathrm{~b}$ & $30.6 \mathrm{a}$ \\
\hline $\mathrm{RC}+\mathrm{MS}$ & $27 \mathrm{ab}$ & $39.2 \mathrm{ab}$ & $26.5 \mathrm{a}$ \\
\hline $\mathrm{RC}$ & $24 \mathrm{~b}$ & $36.1 \mathrm{~b}$ & $8.9 \mathrm{~b}$ \\
\hline $\mathrm{CV}(\%)$ & 12.89 & 5.52 & 20.2 \\
\hline
\end{tabular}

* Means followed by distinct letters in column significantly differ from each other by the Tukey test at $5 \%$ probability. ${ }^{* *} \mathrm{CV}$, coefficient of variation, $\%$.

The emergence speed index was lower in treatment RC (Table 2), confirming that climate factors imposed on the sowing line uncovered surface, like the absence of rainfall, and associated to an increase of solar radiation throughout the germination process (Figure 01), favored the water evaporation on soil surface. In addition, the employment of $\mathrm{RC}$ requires adoption of return mechanisms of straw to sowing line in order to protect soil surface against water losses and improve plant emergence. The same pattern was not observed in treatments involving $C D$, which means that the adoption of covers associated to CD did not improve results of seed ling emergence.

The results of ESI (Table 2) are divided into two statistical groups, one with averages ranging from 26.5 to $34.9 \%$ day $^{-1}$, consisting of treatments CD+CM, CD+M1, CD, RC+CM, RC+M1, $\mathrm{RC}+\mathrm{SM}$, and another with $8.9 \% \mathrm{day}^{-1}$ composed only of treatment RC. The results with the greatest averages in the first group are superior to the ones found by FALLAHI \& RAOUFAT (2008) that obtained values between 15.0 and $18.8 \%$ day $^{-1}$, working with cutting disc and row cleaners, respectively. Yet, treatment RC is close to the findings of FERNANDES et al., (2005), which varied from 9.1 to $10.0 \%$ day $^{-1}$, when evaluating furrow mechanis ms and compactors. FAGANELLO et al. (1998) verified that differences in emergence speed index in maize culture, in condition of vetches straw, were due to individual characteristics of each type of furrower.

It can be noted in data from Table 3 that soil water content was uniform in the occasion of sowing so the variations occurred due to treatments. The absence of coverage on line influenced accentuated water loss on sowing line, in the evaluated depths, which might have interfered on seed germination. These behaviors are related to treatment RC, which means that without straw relocation on sowing line, lower values of soil moisture occurred, for the occasions and evaluated depths. At depth of $0.03 \mathrm{~m}$ in the beginning of emergence, all treatments containing $\mathrm{RC}$ in their arrangements exhibited lower values of soil water contents, not differing only from CD. Therefore, straw relocation on line must be considered as very appealing for preservation of soil water content and that, even without promoting soil movement, the RC mechanism provides quicker water loss on soil superficial layers. According to observations of ANDRADE (2010), the use of deceased 
coverage on soil surface induces the reduction on water losses through evaporation from 19 to $42 \%$, respectively, for 3 and $6 \mathrm{Mg} \mathrm{ha}^{-1}$ of oat straw compared to uncovered soil.

TABLE 3. Soil water content $(\%)$ on sowing line during implantation, in the beginning and the end of the emergency depending on the depth of evaluation, and sowing depth - SD (m) and straw coverage on soil $(\%)$.

\begin{tabular}{lccccccc}
\hline \multirow{2}{*}{ Treatments } & \multicolumn{9}{c}{ Soil water content $(\%)^{*}$} & \multirow{2}{*}{ SD } & $\begin{array}{c}\text { Coverage } \\
\text { (Straw) }\end{array}$ \\
\cline { 2 - 7 } & Implantation & \multicolumn{1}{c}{ Beggining of emergence } & End of emergence & & $\mathrm{M}$ & $\%$ \\
\cline { 2 - 7 } & $0-0.06 \mathrm{~m}$ & $0-0.03 \mathrm{~m}$ & $0.031-0.06 \mathrm{~m}$ & $0-0.03 \mathrm{~m}$ & $0.031-0.06 \mathrm{~m}$ & & \\
\hline $\mathrm{CD}+\mathrm{CM}$ & $38.0^{\mathrm{ns}}$ & $24.7 \mathrm{ab}$ & $37.4 \mathrm{a}$ & $18.4 \mathrm{c}$ & $35.1 \mathrm{a}$ & $0.036 \mathrm{~b}$ & $89.0 \mathrm{ab}$ \\
\hline $\mathrm{CD}+\mathrm{M} 1$ & 40.8 & $29.6 \mathrm{a}$ & $39.1 \mathrm{a}$ & $29.7 \mathrm{a}$ & $36.5 \mathrm{a}$ & $0.043 \mathrm{a}$ & $93.75 \mathrm{a}$ \\
\hline $\mathrm{CD}$ & 40.4 & $22.4 \mathrm{bc}$ & $32.8 \mathrm{abc}$ & $23.5 \mathrm{abc}$ & $30.0 \mathrm{bc}$ & $0.032 \mathrm{~b}$ & $67.5 \mathrm{c}$ \\
\hline $\mathrm{RC}+\mathrm{CM}$ & 44.4 & $21.9 \mathrm{bc}$ & $36.5 \mathrm{ab}$ & $27.4 \mathrm{ab}$ & $34.8 \mathrm{a}$ & $0.035 \mathrm{~b}$ & $65.5 \mathrm{c}$ \\
\hline $\mathrm{RC}+\mathrm{M} 1$ & 41.3 & $17.7 \mathrm{c}$ & $30.9 \mathrm{abc}$ & $20.1 \mathrm{bc}$ & $32.5 \mathrm{ab}$ & $0.030 \mathrm{~b}$ & $71.5 \mathrm{bc}$ \\
\hline $\mathrm{RC}+\mathrm{SM}$ & 38.4 & $18.0 \mathrm{c}$ & $29.5 \mathrm{bc}$ & $20,7 \mathrm{abc}$ & $31.7 \mathrm{ab}$ & $0.036 \mathrm{~b}$ & $76.5 \mathrm{abc}$ \\
\hline $\mathrm{RC}$ & 43.0 & $11.6 \mathrm{~d}$ & $29.4 \mathrm{c}$ & $9.8 \mathrm{~d}$ & $30.1 \mathrm{c}$ & $0.023 \mathrm{c}$ & $1.0 \mathrm{~d}$ \\
\hline $\mathrm{C} . \mathrm{V} .(\%)$ & 10.32 & 16.03 & 12.44 & 21.42 & 6.05 & 12.25 & 19.2 \\
\hline
\end{tabular}

* Means followed by distinct letters in column significantly differ from each other by the Tukey test at 5\% probability.**CV, coefficient of variation. ${ }^{\text {ns }}$, not significant.

The removal of straw on sowing line, using mechanisms of straw mobilization (Table 3), resulted in distinct soil water contents, demonstrating that treatments containing more than $65.5 \%$ of straw $(\mathrm{RC}+\mathrm{CM}) \mathrm{kept}$ at least $30 \%$ of soil water content at depths from 0.031 to $0.06 \mathrm{~m}$ at the end of maize seedlings emergence. Nevertheless, at the depths from 0 to $0.03 \mathrm{~m}$, only treatment CD+M1 presented percentages close to the ones from the lower layer, in which soil water content was $29.7 \%$ with $93.75 \%$ of coverage with straw and greater sowing depth, granting better conditions for seed germination.

Regarding temperature, the results illustrated on Table 4 suggested that the differences on straw coverage on soil altered the soil temperature at $3 \mathrm{pm}$, where treatment RC displayed higher average value. This confirms that coverage acts on protection of soil from solar radiation and not on convection, which means temperature drop of soil surface that occurs during the night. This is another confirmation that soils should remain covered in tropical conditions. The daytime variation of temperature can explain the reduction in availability of water on soil surface previously verified and discussed.

The results suggested that low percentages of straw coverage on sowing line surface found in treatment $\mathrm{RC}$ (Table 3) brought average soil temperatures at $03: 00 \mathrm{pm}$ of $24.1^{\circ} \mathrm{C}$ (Table 4). Therefore, the addition of greater percentages of straw on line compelled with the decrease of soil temperature to $21.2^{\circ} \mathrm{C}$ in treatment $\mathrm{CD}+\mathrm{M} 1$. However, different percentages of straw coverage did not interfere thermally at 09:00am, possibly due to little time of exposition to sunlight according to observation from CONCEIÇÃO et al. (2000). 
TABLE 4. Average soil temperature at depth of $0.05 \mathrm{~m}$ in the line at 09:00am and 3:00 pm, during the emergence of maize seeds.

\begin{tabular}{lcc}
\hline Treatments & $17.9^{\mathrm{ns}}$ & Temperature $\left({ }^{\circ} \mathrm{C}\right) *$ \\
\hline $\mathrm{CD}+\mathrm{CM}$ & 17.8 & $21.7 \mathrm{bc}$ \\
\hline $\mathrm{CD}+\mathrm{M} 1$ & 17.8 & $21.2 \mathrm{c}$ \\
\hline $\mathrm{CD}$ & 17.8 & $22.0 \mathrm{~b}$ \\
\hline $\mathrm{RC}+\mathrm{CM}$ & 17.8 & $22.1 \mathrm{~b}$ \\
\hline $\mathrm{RC}+\mathrm{M} 1$ & 17.8 & $22.4 \mathrm{~b}$ \\
\hline $\mathrm{RC}+\mathrm{SM}$ & 17.8 & $24.1 \mathrm{a}$ \\
\hline $\mathrm{RC}$ & 1.36 & 2.12 \\
\hline $\mathrm{CV}(\%)^{* *}$ & & $5 \mathrm{p}$ \\
\hline
\end{tabular}

* Means followed by distinct letters in column significantly differ from each other by the Tukey test at $5 \%$ probability. ${ }^{* *} \mathrm{CV}$, coefficient of variation. ${ }^{\mathrm{ns}}$, not significant.

Table 5 reveals that straw coverage on soil (CS), the emergence speed index (ESI), sowing depth (SD) and soil water content at depth of 0-0.03 m(CAS P1) presented distinct correlations and in inverse proportion (negative) with temperature evaluated at $3: 00 \mathrm{pm}$, and also exhibited highly significant statistical results by $\mathrm{T}$ test. This occurred because of the effect of straw on sowing line represented by CS that provided maintenance of water content and soil temperature at $03: 00 \mathrm{pm}$, improving emergence speed of maize seedlings, due to validated benefits that straw brings on sowing line. This behaviors demonstrates that a rise in percentage of maize seedlings emergence are indirectly achieved with a drop in soil temperature due to buffering effect of water on temperature (BRANDELERO et al., 2012b), given that straw contributes considerably to maintenance of water environment on line as well as easing sunlight effects on soil.

The soil coverage on sowing line (CS) suggested strong correlations with emergence speed index (ESI) and highly significant by $\mathrm{T}$ test (Table 05) reinforcing that straw enhances percentage of emerged plants through its maintenance effects of soil water content and temperature.

It is important to highlight that, in this study, extreme variations of temperature on soil were not tested but that, at the range of average soil temperature of $17.8^{\circ} \mathrm{C}$ at $09: 00 \mathrm{am}$ and of $22.4^{\circ} \mathrm{C}$ at 03:00 pm, satisfactory percentages of maize seedling emergence speed occurred, varying from 8.9 to $34.9 \%$ day $^{-1}$. Straw acted positively on the maintenance of water content and soil temperature. This relation of straw with water content and temperature on soil surface was also evidenced by FALLAHI \& RAOUFAT (2008); contributing to the raise in ESI in treatment that straw remained on line surface. 
TABLE 5. Simple linear correlation coefficients (r) for the analyzed variables of straw coverage on soil (CS), emergence speed index (ESI), seed water content (SWC), sowing depth (SD), soil temperature at 09:00am (T 9hs), soil temperature at 03:00pm (T 15hs), soil water content at a depth between 0 to $0.03 \mathrm{~m}$ (CAS P1) and soil water content at depth from 0.031 to $0.06 \mathrm{~m}$ (CAS P2).

\begin{tabular}{|c|c|c|}
\hline Correlation & Coef. (r) & Signif \\
\hline$\overline{C S} \times \mathrm{ESI}$ & 0.8012 & $* *$ \\
\hline CS x SWC & 0.5014 & $* *$ \\
\hline $\mathrm{CS} \times \mathrm{SD}$ & 0.6089 & $* *$ \\
\hline CS x T 9hs & -0.1426 & ns \\
\hline CS x T 15 hs & -0.8938 & $* *$ \\
\hline CS x CAS P1 & 0.8644 & $* *$ \\
\hline CS x CAS P2 & 0.5461 & $* *$ \\
\hline ESI x SWC & 0.1749 & ns \\
\hline ESI x SD & 0.4223 & $*$ \\
\hline ESI x T 9hs & -0.3288 & ns \\
\hline ESI x T $15 \mathrm{hs}$ & -0.7849 & $* *$ \\
\hline ESI x CAS P1 & 0.7701 & $* *$ \\
\hline ESI x CAS P2 & 0.4931 & ** \\
\hline SWC x SD & 0.3360 & ns \\
\hline SWC x T 9hs & 0.1594 & ns \\
\hline SWC x T 15hs & -0.3363 & ns \\
\hline SWC x CAS P1 & 0.3338 & ns \\
\hline SWC x CAS P2 & 0.3878 & $*$ \\
\hline SD x T 9hs & -0.1805 & ns \\
\hline $\mathrm{SD} \times \mathrm{T} 15 \mathrm{hs}$ & -0.5614 & $* *$ \\
\hline SD x CAS P1 & 0.6182 & $* *$ \\
\hline SD x CAS P2 & 0.5093 & $* *$ \\
\hline T 9hs x T 15hs & 0.2615 & ns \\
\hline T 9hs x CAS P1 & -0.4407 & $*$ \\
\hline T 9hs x CAS P2 & -0.3345 & ns \\
\hline T 15 hs x CAS P1 & -0.8637 & $* *$ \\
\hline T 15 hs x CAS P2 & -0.5461 & $* *$ \\
\hline CAS P1 x CAS P2 & 0.7989 & $* *$ \\
\hline
\end{tabular}

\section{CONCLUSIONS}

The employment of return mechanisms provided maintenance of straw on sowing line and contributed to an increase in emergence speed index, when compared to row cleaner's treatment operating alone. The maintenance of straw on sowing line by return mechanisms acted positively on maintenance of water content and soil temperature. The removal of straw by row cleaners, when operating individually, and low sowing depth results in lower emergence speed indexes of seedlings due to water limitations occurred on germination environment.

\section{ACKNOWLEDGEMENTS}

This study was conducted with financial support from National Council for Scientific and Technological Development - CNPq. The first author also thanks the State University of Londrina by means of the Post Graduation Program in Agronomy, for the opportunity to obtain the title of Doctor, as well as the Agronomic Institute of Paraná - IAPAR for the assistance in conduction of the project. 


\section{REFERENCES}

ANDRADE, J.G. Influência dos resíduos vegetais na superfície do solo na dinâmica de evaporação da água e temperatura do solo 2010. 92f. (Dissertação de Mestrado em Ciência do Solo) Universidade Federal de Santa Maria, Santa Maria, 2010.

ARATANI, R.G.; MARIA, I.C.de; CASTRO, O.M. de; PECHE FILHO, A.; DUARTE, A.P.; KANTHACK, R.A.D. Desempenho de semeadoras-adubadoras de soja em Latossolo Vermelho muito argiloso com palha intacta de milho. Revista Brasileira de Engenharia Agrícola e Ambiental, Campina Grande, v.10, n.2, p.517-522, 2006.

BRANDELERO, E.M.; ARAUJO, A.G.; RALISCH, R. Desempenho de uma semeadora direta equipada com diferentes mecanismos para a mobilização da palha na linha. In: CONGRESSO BRASILEIRO DE EN GENHARIA AGRÍCOLA, 41., 2012, Londrina. Anais... Londrina: Associação Brasileira de Engenharia Agrícola, 2012a. 1 CD-ROM.

BRANDELERO, E.M.; ARAUJO, A.G.; RALISCH, R. Mecanismos para o manejo da palha na linha de semeadura e seus efeitos no ambiente germinativo das sementes de milho. In:

CONGRESSO BRASILEIRO DE ENGENHARIA AGRÍCOLA, 41., 2012, Londrina. Anais... Londrina: Associação Brasileira de Engenharia Agrícola, 2012b. 1 CD-ROM.

CARVALHO, N. M. de Sementes: ciência, tecnologia e produção. 4. ed. Jaboticabal: Funep, 2000. $588 \mathrm{p}$.

CEPIK, C.T.C.; TREIN, C.R.; LEVIEN, R.; CONTE, O. Força de tração e mobilização do solo por hastes sulcadoras de semadoras-adubadoras. Revista Brasileira Engenharia Agrícola e Ambiental, Campina Grande, v.14, n.5, p.561-566, 2010.

CHIODEROLI, C.A.; FURLANI, C.E.A.; SILVA, R.P.da; GITTI, D.deC.; KANEKO, F.H.; ROMAN, R.A.A. Desempenho de semeadora - adubadora em função do preparo de solo e espaçamento da cultura do milho. Pesquisa Agropecuária Tropical, Goiânia, v.40, n.4, p.462-467, 2010 .

CONCEIÇÃO, M.J.; WOHLENBERG, E.V.; ZIMMERMANN, F.L.; CARLESSO, R.; REICHERT, J.M. Temperatura, umidade do solo e emergência de milho em diferentes sistemas de manejo. In: REUNIÃO BRASILEIRA DE MANEJO E CONSERVAÇÃO DO SOLO E DA ÁGUA, 13. 2000, Ilhéus. Anais...

CONTE, O.; LEVIEN, R.; TREIN, C.R.; XAVIER, A.A.P.; DEBIASI, H. Demanda de tração, mobilização do solo na linha de semeadura e rendimento da soja, em plantio direto. Pesquisa Agropecuária Brasileira, Brasília, v.44, n.2, p.1254-1261, 2009.

EMBRAPA - Empresa Brasileira de Pesquisa Agropecuária. Centro Nacional de Ciênc ia do Solo. Manual de métodos de análise do solo. Rio de Janeiro, 1997. Não paginado.

FAGANELLO, A.; SATTLER, A.; PORTELLA, J.A. Eficiência de semeadoras na emergência de plântulas de milho (Zea maiz), sob sistema plantio direto. In: CONGRESSO BRASILEIRO DE ENGENHARIA AGRÍCOLA, 27., 1998, Poços de Caldas. Anais... Lavras: UFLA/SBEA, 1998. p.229-231.

FALLAHI, S.; RAOUFAT, M.H. Row-crop planter attachments in a conservation tillage system: A comparative study. Soil \& Tillage Research, Kidlington, v.8, n.98, p.27-34, 2008.

FERNANDES, H.C.; REIS, E.F.DOS; NAIME, J.DEM.; MODOLO, A.J.; RINALDI, P.C.N. Utilização da tomografia computadorizada para determinação da densidade do solo na região da semente. Engenharia na Agricultura, Viçosa, v.13, n.2, p.82-94, 2005. 
KOAKOSKI, A.; SOUZA, C.M.A.de; RAFULL, L.Z.L.; SOUZA, L.F. de; REIS, E.F.dos Desempenho de semeadora - adubadora utilizando-se dois mecanismos rompedores e três pressões da roda compactadora. Pesquisa Agropecuária Brasileira, Brasília, v.42, n.5, p.725-731, 2007.

KORNECKI, T. S.; RAPER, R. L.; ARRIAGA, F. J.; SCHWAB, E. B.; BERGTOLD, J. S. Impact of rye rolling direction and different no-til row cleaners on cotton emergence and yield.

Transactions of the ASABE, Joseph, v.52, n.2, p.383-391, 2009.

LAFLEN, J.M.; AMEMIYA, M.; HINTZ, E. A. Measuring crop residue cover. Journal of soil and Water Conservation, Ankeny, v.36, n.6, p.341-43, 1981.

LEVIEN, R; FURLANI, C.E.A.; GAMERO, C.A.; CONTE, O.; CAVICHIOLI, F.A. Semeadura direta de milho com dois tipos de sulcadores de adubo, em nível e no sentido do declive do terreno. Ciência Rural, Santa Maria, v.41, n.6, p.1003-1010, 2011.

ROSA, D.P. da. Relação solo-máquina-planta num Argissolo cultivado e sob campo nativo. $109 f$. Tese (Doutorado em Engenharia Agrícola) - Universidade Federal de Santa Maria, Santa Maria, 2009.

ROSA, D.P.da; REICHERT, J.M.; MENTGES, M.I.; DA ROSA, V.T.; VIEIRA, D.A.; REINERT, D.J. Demanda de tração e propriedades físicas de um Argissolo em diferentes manejos e intensidades de tráfego. Pesquisa Agropecuária Brasileira, Brasília, v.47, n.1, p.118-126, 2012.

ROSA, D.P. da; REICHERT, J.M.; SATTLER, A.; REINERT, D.J.; MENTGES, M.I.; VIEIRA, D.A. Relação entre solo e haste sulcadora de semeadora em Latossolo escarificado em diferentes épocas. Pesquisa Agropecuária Brasileira, Brasília, v.43, n.3, p.395-400, 2008.

SANTOS, A.P.; TOURINO, M.C.C.; VOLPATO, C.E.S. Qualidade de semeadura na implantação da cultura do milho por três semeadoras-adubadoras de plantio direto. Ciência Agrotécnica, Lavras, v.32, n.5, p.1601-1608, 2008.

SCHNEIDER, E.C.; GUPTA, S.C. Corn emergence as influenced by soil temperature, matricial potencial, and aggregate size distribution. Journal Soil Science Society American, Madison, v.49, n.2, p.415-422, 1985.

VEIGA, M.; REINERT, D.J.; REICHERT, M.J. Sistemas de manejo e fontes de nutrientes afetando cobertura, temperatura e umidade de um latossolo argiloso sob milho. Revista Brasileira Ciência do Solo, Viçosa, MG, v.34, n.6, p.2011-2020, 2010.

SILVA, F.deA.S.E.; AZEVEDO, C.A.V.de Principal Components Analysis in the Software Assistat-Statistical Attendance. In: WORLD CONGRESS ON COMPUTERS IN AGRIC ULTURE, 7., 2009, Reno. Proceedings... Reno: American Society of Agricultural and Biological Engineers, 2009. 